\title{
1. Financialization and the corporation in the twenty-first century
}

The corporation is neither a naturally occurring phenomenon nor a manifestation of human nature. It is a social construct; a product of extrinsic agency. It is a social invention; a form of public intervention (see Hamilton 1956). Enterprise does not require the corporate form in order to engage in production or commerce. However, in the past 130 years corporations have become a common method to conduct business in the United States (US).

The corporation 'as a form of social organization is peculiar to western culture' (Hamilton 1956, p. 12). How did the corporate form become such a favored model for business organizations? What purpose did it serve in the development of the modern economy of the US? How did it achieve the characteristics of a person for purposes of law? How did corporations come to exercise so much power in the US? Those questions will be answered in this book. The corporation as we know it today is the outcome of a process of co-evolution as the economy developed, business adapted to the development, finance supported that adaptation and courts endorsed the emerging business practices. The corporation is a result of cumulative causation.

Corporations have 'persisted for millennia, with roots in the church, local government communes, and early business companies' (Davis 2016, p. 612). Roman law governed the formation and operation of 'public and private corporate bodies' (Hurst 1970, pp. 1-2). The medieval church governed ecclesiastical corporate bodies. These corporations required an act by the sovereign (secular or sectarian) to be called into existence (Hurst 1970, p. 2). The lever of public control over the purposes and powers of corporations is clear. The sovereign authority creates the corporation.

In early modern Europe the 'corporation was most clearly represented by the guild and commune' (Davis 2016, p. 613). The public authority of the sovereign over corporations under church law and Roman law is analogous to English law on corporations although there 'is little indication that English policy makers followed, or even knew much, Roman doctrine' (Hurst 1970, p. 2). 'By 1628 Coke could assert firmly that royal authorization was necessary to create a corporation' (Hurst 1970, p. 3). Public sovereignty over corporations developed as a national English government asserted authority over local governments. 
Granting of royal charters by the sovereign carried over to the North American colonies. Such charters also commanded the corporations to be responsible to the sovereign and the public. The formation of corporations in the North American colonies was not widespread and when corporations were chartered it was primarily for local public services. 'It appears that only seven business corporations were created in the Thirteen Colonies' (Sylla 2014, p. 355). Some of the royal grants of charters survived the Revolution, such as the one discussed in Chapter 3 which was a charter granted by King George III to the Reverend Eleazar Wheelock to create Dartmouth College in 1769 for the purpose of maintaining and educating the children of Native Americans.

The authority of the sovereign to grant charters was a power assumed by state governments after the Revolution (Davis 1917, p. 4). Charters issued by state governments in the early years of the US were 'for activities of some community interest - supplying transport, water, insurance or banking facilities. That such public interest undertakings practically monopolized the corporate form implied that the public authority must confer it' (Hurst 1970, p. 15). John R. Commons described the corporate charter as 'the group of promises and commands which the state makes in the form of working rules indicating how the officials of the state shall act in the future in matters affecting the association, the members of the association, and the persons not members' (Commons 1924, p. 144). The grant of a charter had the effect of personifying the association of persons as a collective entity upon which the state imposed rights, duties, liabilities and exposures (Commons 1924, p. 143). The corporation, however, was not merely an association of persons. It had an independent existence by reason of its charter granted by the state.

Corporations 'could not exist a day if the sovereign power of the State were not back of them, giving them the rights to buy and sell and hold property, and to act as a single aggregation of capital, with all the enormous power which this implies' (Commons 1894, p. 62). Commons observed how this relationship between the corporation and the state was social control. 'If the State creates corporations, it can determine the conditions of their existence' (Commons 1894, p. 62). The earliest development of corporations in the US emphasized this relationship and the public purpose of corporations.

Between 1781 and 1800 state legislatures granted 333 charters for corporations (Davis 1917, pp. 22-3). Only 28 charters for ordinary business corporations were granted up to 1790 (Sylla 2014, p. 355). The role of the public interest dominated the formation of corporations during the eighteenth and nineteenth centuries. Businesses during the eighteenth and much of the nineteenth centuries were small and often family owned (Tung 2006, p. 46). Corporations were not the dominant form of organization for business enterprises during this period when sole proprietorships and partnerships represented the bulk of business organizations (Davis 1917, p. 256). 
During the entire eighteenth century only 355 corporations were chartered and many of them were chartered for municipal or charitable purposes (Friedman 1973, p. 166). The corporations formed under acts of state legislatures, known as special charters, were engaged in local public services, construction and maintenance of highways and banking. Only 4 percent of the charters were for ordinary business corporations (Davis 1917, pp. 24-5). Up to the Civil War most of the corporations were small business entities (Sylla 2014, p. 356). Each of the corporations was granted a special charter as a separate act of a state legislature. These special charters granted specific powers to the corporation and imposed limits, such as the number of years the corporation could continue - not all corporations were granted a perpetual life. The charters also limited the corporation under such terms as (1) how it could conduct business, (2) setting an upper limit on its paid-in capital and (3) prohibiting mergers.

The widening of the market as a result of westward expansion, first through canals, followed shortly by railroads and the development of a communication infrastructure in the mid-nineteenth century, would not be served by the handicraft production methods which marked the late eighteenth and early nineteenth centuries. The earlier period where handicraft production predominated was characterized by John R. Commons as the 'age of scarcity'. The doubling of miles of railroad track between 1870 and 1880, the development of power sources beyond water making the location of plants away from rivers possible, the communication infrastructure of the telegraph with more than 50000 miles of telegraph wire by 1860 and the interstate Commerce Clause of the United States Constitution which limited state intervention encouraged the growth of industrial enterprises in what Commons called the 'age of abundance'. Expanding industrial enterprises and abundance of product resulted in cutthroat price competition and an extended period of deflation after the Civil War extended into the late nineteenth century. Abundance and the associated deflation threatened the stability of revenues required to meet the costs of production and debt service for these large-scale industrial enterprises.

Increased reliance on corporate organization of business was about stabilization of revenues, control over the production process, control over the advancing technology and creating liquidity.

At first, stabilization efforts were directed towards the control of the production processes. These efforts finally flowered into the modern holding company which brought both vertical and horizontal integration to the basic industries of the nation. In more recent years the stabilization program has been extended from the production processes to the realm of finance and monetary arrangements. (Gruchy 1947, p. 197) 
Cutthroat price competition and the prospects of deflation affected the financial interests extending credit to the corporations. The financial interests fostered restrictions on output to achieve 'stabilized scarcity' and stabilized revenue (Gruchy 1947, p. 192).

The process of economic development in the US accelerated during the middle years of the nineteenth century as the market expanded. The expansion arising first from canals then railroads and telegraph propelled the economy through changes which would affect business. John R. Commons identified the stages of such changes as merchant capitalism, employer capitalism and banker capitalism. These stages in the development of capitalism were characterized first by transformation of production and then by transformation of finance. Commons' analysis explains the replacement of an age of scarcity where handicraft production was predominated by an age of abundance where mass industrial production resulted in the 'menace of competition' that was replaced by price and profit stabilization through business consolidation (Commons 1934, pp. 763-88). 'Capitalistic organization of various industries, as opposed to earlier craft organizations, developed with the widening of markets, and the consequent opportunity for mass production and standardization of products' (Mitchell 1927, p. 72). The corporation as the dominant mode of business organization occurred as the financial system developed to accommodate the changes in industrial production.

The use of the corporate form for the organization of business during the latter decades of the nineteenth century was the outcome of the economic circumstances and laws endorsing emerging business practices. Business in response to the expanding markets engaged in roundabout production entailing extensive time delays between production and sale. This delay and the increasing scale of production required finance to manage the uncertainty of revenues. However, 'what appears to be a sudden transformation from a production economy to a financial one is actually an evolutionary process that can be traced back for several decades' (Atkinson 2010, pp. 289-90). The consequences of the co-evolution of the corporation, finance and the law carried the practices of the late nineteenth century forward into contemporary times.

Justice Oliver Wendell Holmes, Jr., in his dissent in one of the early decisions of the US Supreme Court applying the Sherman Antitrust Act of 1890 , observed that 'every concern monopolizes whatever business it does' (Northern Securities Co. v. US, 193 US 197, 406 (1904)). The tendency of business toward excluding competitors from the market was not new to the nineteenth century. The response of business to the menace of competition in the latter decades of the nineteenth century took this process to extremes as business sought to stabilize prices and revenues through a combination of competitors. 
An expanded legal definition of property that included for the first time constitutional protections for intangible property was formulated by the courts in the latter decades of the nineteenth century and adopted by the US Supreme Court in 1890. The role of finance in the management of business was promoted by this change extending the protections of the Fourteenth Amendment to intangible property. The use of the corporate form to facilitate mergers was made possible by legislative changes to the laws regarding the purposes for which a corporation was organized and by the courts' interpretation of antitrust law. Judicial positions such as (1) manufacturing not being interstate commerce even if the product was to be sold in another state and (2) the judicial creation of the Rule of Reason by the Supreme Court in its interpretation of the Sherman Antitrust Act permitted the consolidation of competitors into monopolies. The significant growth of corporations in the final two decades of the nineteenth century and the first decade of the twentieth century introduced finance directly into the control of the new monopolies. The valuation of corporations came to be based upon their intangible property which made protection of the stream of revenues central to the operation of industrial enterprises.

As originally described by Thorstein Veblen in The Theory of Business Enterprise (1904), the late nineteenth century represented a turning point in the organization of American industry. This shift in industry was accompanied by a shift in financial practices, one Veblen described as the movement from a money economy to a credit economy. With the rise of the credit economy, a new way of organizing, reorganizing and extending ownership claims came into practice.

The merger wave of 1895-1904 brought competitors into new consolidated businesses where prices could be more effectively administered and output of product could be restrained for that purpose. Financiers would be a critical component of this process as 'the banking syndicate or the investment banker, usually affiliated with commercial banks, arose out of their former intermittent activity in special flotations of securities of corporations and nations, into a dominant position in the consolidation of industries' (Commons 1934, p. 773). A corporation was the tool for such consolidation because its stock could be used to acquire competitors. The growth of a stock exchange was stimulated by owners of smaller companies involved in mergers who wanted to trade part of their equity for more liquid assets (Navin and Sears 1955, p. 116). Consolidation of business under a corporation served to expand 'ownership claims without any necessary concomitant expansion of productive apparatus' (Hamilton 1956, p. 14). Corporations became a means for creating income claims on industry while simultaneously coordinating its productive capacity in order to stabilize revenues.

With large corporations operating under boards of directors influenced directly by financiers, the focus of the corporation would be on producing 
pecuniary values - streams of revenue to service debt, cover the costs of production and insure a profit. The development of law which (1) legitimized mergers to reduce cutthroat competition, (2) protected the corporation from economic regulation by reliance on the Fourteenth Amendment protections as applied to intangible property and (3) vested the board of directors of a corporation with the predominant role of determining how its funds would be used, would make the corporate form the preferred form for large-scale industrial production. With the growth of corporations and the role of financial interests in the economy, this period provided the foundation for the financialization of the US economy.

\section{THE CORPORATION AND FINANCIALIZATION}

Endorsements by courts and legislatures of business practices to stabilize revenues and protect the vested interests had consequences for the co-evolution of industry and finance (Atkinson and Whalen 2011, pp. 58-65). In the 1930s John R. Commons, Adolf A. Berle and Gardiner C. Means connected the structure of industry to the co-evolution of law, corporations and finance. Hyman Minsky observed and analyzed the increasing role of finance in the US economy. The effect of finance on industrial enterprises affected the broader financialization of the economy.

Commons analyzed the expansion of the legal definition of property to include intangible property and noted the role of finance in industrial enterprises which he described as 'going concerns' (Commons 1909; Commons 1934; Mitchell 1927; Veblen 1904). The value of tangible property relates to the physical assets of a going concern. Intangible value rests on the expected future exchange value of the going concern.

Mass production to serve the wider markets meant that factories required expensive equipment. The investment in equipment created the need for accommodative financial institutions (Atkinson and Whalen 2011, p. 60). Inventories also had to be financed which were not required in the handicraft economy. Roundabout production for the wider market meant that the time between production of goods and receipt of income was longer.

Railroads adopted the corporate form of ownership earlier than other industries in this period of industrial development. The corporate entity was used to raise large amounts of financial capital. Corporate organization centralized management of their far-flung operations. The railroad tycoons quickly turned to finance rather than simply managing the tangible property. 'They [corporate directors] were coming more and more in their fiscal transactions to deal in stocks and bonds, in rights to property rather than in physical property itself' (Cochran and Miller 1942, p. 151). The focus on finance was a consequence of the emergence of intangible property. 
Increased use of the corporate form to serve private financial interests diminished social control over the corporation. As states replaced special charters with general incorporation statutes they ceded social control. Corporations flourished under state laws permitting them to consolidate through the "trust approach' to consolidation. Federal efforts to impose social control through antitrust laws failed to limit the growth of large corporations controlling substantial market shares. The power exercised through market shares allowed corporations to achieve stabilized scarcity over output resulting in stabilization of revenues serving the interests of financiers.

Berle and Means (1932) added to the awareness of the evolution of the corporation and property. With corporations increasing in size and spreading to many industries, stock ownership became widespread. Few shareholders had any power over the operations of the corporations they owned (Berle and Means 1932, p. 64). The shareholders were interested in earnings and the liquidity of their holdings - to be sold at a gain. In his 1967 Preface to the revised edition, Berle observed "that stock markets are no longer places of "investment" as that word is used by classical economists. Save to a minimal degree, they no longer allocate capital. They are mechanisms for liquidity' (Berle and Means 1932, p. xxxiii). Mature corporations do not rely on investors to supply capital. In an economy of administered prices corporations set prices high enough to finance the production capital of the going concern. They tap individual investors for a little less than 20 percent of their capital through the issuance of bonds to institutions such as life insurance companies, trust funds, pension trusts and savings banks (Berle and Means 1932, p. xxvii). The role of finance in these corporations operating without serious social control made the pecuniary value of the corporation preeminent for its owners without regard to the role which the states had in bringing such entities into existence.

\section{THE CO-EVOLUTION OF ECONOMICS, LAW AND FINANCE}

The financialization of the global economy was built upon the arguments and theories of modern macroeconomics and finance. In response to the Keynesian synthesis of the 1950s that justified government policies to manage total effective demand and regulate an unstable financial system, the monetarist and new classical arguments were worked out in the late 1960s and 1970s. This body of work involved a recasting of classical theories of economics: the quantity theory of money, a market-generated general equilibrium and the efficiency of process innovations in the context of perfect and complete markets. This revolution in economic thought had an enormous and lasting impact on the discipline. Most of the principal authors were recognized for their influence on the profession with the Nobel Memorial Prize in Economics. 
First steps in creating this new dominant paradigm included the mathematical proof of general equilibrium provided by Kenneth Arrow and Gerald Debreu (1954) and John Muth's (1961) development of the rational expectation assumption for agent behavior. While the dominant Keynesian view argued that the instability of the macroeconomic system was internally generated, the Arrow and Debreu proof demonstrated that markets could (under specific assumptions) create a perfectly efficient distribution of incomes and output. According to John Muth's theory of rational expectations, agents form rational expectations about relevant variables and then take action in an environment of incomplete information. Through a process of discovery and refinement, efficient allocations are created. John Muth's argument became the foundation for the New Classical approach to economics, and the primary charge that Keynesian macroeconomics lacked a firm 'microeconomic foundation'.

A second major step involved the work of Milton Friedman (1968) to revitalize the quantity theory of money, the classical theory linking changes in the price level to the money supply. This body of work was christened monetarism by Karl Brunner in 1968. Friedman's restatement of the quantity theory of money was originally developed as a theory of money demand based on permanent income and inflation expectations. As it was developed, the ability of monetary authorities to control the money supply, and the consequent level of nominal gross domestic product (GDP), was confirmed. From the monetarist perspective business cycles were not caused by the internal instability of finance and animal spirits, but by misguided monetary policy.

While monetarism included core assumptions (stable money velocity) and policy conclusions (a stable money growth rate rule to control inflation expectations) that proved unworkable, monetarism established several key components of modern macroeconomics. These included the natural rate of unemployment hypothesis, fluctuations in economic activity as movements around underlying real trends, the primacy of monetary over fiscal policy as a tool of stabilization and the ineffectiveness of interventionist government policy to stabilize economic activity (Snowdon and Vane 2005, p. 197).

The work of Robert Lucas, Jr. is recognized as a more damaging criticism of Keynesian macroeconomics. As argued, the Keynesian model divorced macroeconomics from the assumptions of rational economic agents - creating a schism between the macroeconomics of fundamental instability and the foundations of microeconomic analysis and market equilibrium. Expanding upon the rational expectations hypothesis of John Muth (1961), Lucas developed an explanation of macroeconomic phenomenon that was collectively recognized as the basis of a new school of thought - New Classical Economics. This school of thought and modeling re-established the equilibrium approach of continuous market clearing, competitive markets and rational agents. 
According to this theory, individual rational agents, operating in competitive markets with incomplete information, could create a general equilibrium that achieved a long-run maximization of output, determined by the state of technology, and efficiently allocate capital, risk and incomes. The key criteria to achieve this result was the observation that rational agents, both suppliers and workers, could make mistakes in allocation decisions because of unanticipated changes in macroeconomic variables - such as the money supply or inflation. Internally generated change in the expectations of risk or expected income was not considered a destabilizing force.

Because rational agents would be able to instantaneously respond to anticipated changes in policy mechanisms, this model produced the famous Lucas critique of Keynesian interventionist strategies. If the government engaged in discretionary fiscal policy or monetary policy, these changes to the macroeconomic environment would be recognized as anticipated changes, resulting in no deviation from long-run equilibria allocation decisions. Because macroeconomic policy could not be based on making unanticipated changes without disrupting the information environment of the agents and destabilizing their expectations of the future, the use of discretionary monetary and fiscal policy was irrelevant to managing the macroeconomy.

To understand the drift towards a new financial system, this New Classical school of thought provides a key basis for the resurgent view of market efficiency. The key to improving the operation of the macroeconomy came from the creation of more complete, complex, perfectly competitive markets capable of instantaneously integrating any information as it became available. Momentary fluctuations away from long-run growth rates would then be reduced.

The equilibrium analysis of financial markets was developed in the efficient markets hypothesis (EMH) of Eugene Fama (1970). According to the EMH, financial markets are capable of digesting and incorporating new information to produce an efficient market equilibrium. Because market agents are rational, there is no need for government intervention or oversight to make these markets more efficient in their allocation of capital. The efficiency of financial markets benefits from and encourages more rapid financial innovation - the creation of new products that can separate, categorize and market distinct forms of risk or expected income. This process ensures market participants can more systematically evaluate and price each kind of risk created. They will only extend loans where they are willing to accept the risk, and so efficiently allocate capital to its best possible use.

The work of Fischer Black and Myron Scholes (1973) and Robert Merton (1973) on option pricing models demonstrated their accuracy. This work was necessary as financial instruments became increasingly complex. While derivatives such as futures options have a long history in financial markets, 
the development of the Black-Scholes method of pricing derivative products provided a mechanism that allowed the market to begin growing rapidly in the 1970s. By increasing the ability to analyze and price derivative products, these provided new risk management tools for companies, altering their need to rely upon equity or other traditional sources of finance.

Henry Manne's efficient market for corporate governance (1965) explored the benefit of mergers and acquisitions. In a liquid and transparent equity market, the fluctuations of stock price are seen as real-time evaluations of the quality of the current corporate management. From the perspective of this theory, a more active environment in mergers and acquisitions, later coupled with the use of debt to acquire and reorganize industry structure, improves the organization of the firm. Antitrust regulation on the basis of product prices and public welfare would interfere with the efficient transfer of managerial control.

Coupled with the work of Henry Manne, the theories of corporate agency and control developed by Michael Jensen and William Meckling (1976) created a new perspective on the corporation's efficiency in allocating capital and maximizing the generation of income. This work explained the role of using stock options to resolve the agency problem of management. The use of stock options, providing shares of ownership in the compensation packages of executives, would help align the interest of corporate management with the interests of the stockholders. Because fluctuations of the secondary stock price represented an efficient evaluation of the expected future value of the corporation and corporate strategies, management should maximize that share price, and then reap a share of the benefit by exercising their stock options. Rather than simply aligning the interests of management and firm owners, the use of stock options combined their interests, making the managers at least temporary owners of the firm for the duration of their stock option. Jensen (2004; Jensen et al. 2004) later explored the agency risks that became apparent in the industry standard approach to stock option.

Taken together, the theories of Friedman, Lucas, Eugene Fama, Black and Scholes, Manne, and Jensen and Meckling created a new foundation for the operation of equity and bond markets. These theories became an engine that allowed the remaking of financial markets, rather than a camera that accurately explained their operation (Mackenzie 2006; Lengwiler 2016). This combined view of long-run general equilibrium capable of generating financial market and macroeconomic stability became the framework for New Finance that was already emerging.

The growth of the 1980s and 1990s provided evidence of success. While empirical evidence and research into increasing efficiency provided a microeconomic bedrock of proofs and extensions, macroeconomic outcomes justified the new regime. Indeed, the 'Great Moderation' - of low inflation rates and falling unemployment - was credited to the new economic policy regime. In 
addition to the broad category of good luck, Ben Bernanke argued that this new stability had been caused by superior institutional structures that included the increased depth and sophistication of financial markets and the superior understanding of appropriate monetary policy (Bernanke 2004, p. 1). This new understanding of macroeconomic dynamics even led some to argue that the era of economic instability had finally ended. As noted by Robert E. Lucas, Jr. in his American Economic Association Presidential address, 'The central problem of depression prevention has been solved, for all practical purposes, and has in fact been solved for many decades' (Lucas 2003, p. 1).

\section{FROM THE AGE OF FINANCE TO MANAGERIAL CAPITALISM AND BACK AGAIN}

With the systematic defeat of the Keynesian consensus in the 1970s a new era of American (and global) capitalism could gather speed. In its broadest sense, this shift can be understood in the US as the roll-back of New Deal protections and managerial capitalism that had created a compromise of influence by government agencies, labor unions and business interests. Following the turbulence of the 1970s, this new system included flexible exchange rates and global capital flows, monetary policy focused on disinflation and stable price levels, the hamstringing of progressive taxation, the deregulation of finance and fiscal policy that promised investment and production rather than stabilizing aggregate expenditure.

The record of the twenty-first century, however, has not been so kind to the triumphant optimism of the economics profession. While the reality of increased financial market instability began to appear as early as the Mexican Peso and Savings \& Loans crises of the 1980s, the impact of financial market volatility became increasingly clear as the global economy experienced the 1997 Asian financial crisis, the dot-com bubble of 2000, the global financial crisis of 2008 and the Eurozone crisis of 2010, to name only the most severe.

The problems in 2008 first appeared as a freezing of the credit markets for short-term financing that supported modern finance, then spread to the securitization market. As it became apparent that rising defaults in the underlying securitized assets could spread to the final product, a sudden repricing of risk appeared. As noted by former chairman of the Federal Reserve Alan Greenspan in his testimony before the House Committee on Oversight and Regulation in 2008, the financial crisis exposed a fatal flaw in the models and assumptions that had justified the rise of New Finance and the unsustainable claims on income it could generate. 'The whole intellectual edifice of modern risk management collapsed ... something which looked to be a very solid edifice, a critical pillar to market competition and free markets, did break 
down. I found a flaw in the model that I perceived is the critical functioning structure that defines how the world works' (Greenspan 2008, pp. 13, 46).

\section{FINANCIALIZATION}

The changes of the late twentieth century can be most broadly described as financialization. The motives and structure of finance have penetrated every aspect of economic organization, including the organization of the corporation. The definition of Krippner is commonly cited: 'Financialization is a pattern of accumulation in which profits accrue primarily through financial channels rather than through trade and commodity production' (Krippner 2005, p. 174). Epstein provides a similar broad-ranging statement: 'financialization means the increasing role of financial motives, financial markets, financial actors and financial institutions in the operation of the domestic and international economies' (Epstein 2005, p. 3). While the idea of financialization as a phenomenon or distinct category of economic development has relevant criticism (Michell and Toporowski 2013; Fiebiger 2016), changes in the stability of financial markets, the income shares going to financial markets and the relative size of global financial markets and trading provide evidence that the structure of global capitalism changed during the late twentieth century, and financialization is a useful lens through which to view these changes.

While the categorization of financialization to demarcate the late twentieth-century development of capitalism is commonly used, it is not a new phenomenon for the corporation. As can be seen in the work of Commons, Veblen and Hilferding, the corporation is a legal system of defining and legitimating claims on income. The justifications and theories used to define it are belief systems. In many cases, those theories mystify rather than elucidate the practical working out of the process.

Evidence of financialization is broad ranging. Over the past 50 years, the size of financial market assets in the US has grown from one third of total assets to 45 percent of total assets in 2010. While the value of financial-sector assets was 100 percent of US GDP in the early 1950s, it is now 450 percent of US GDP (Epstein and Crotty 2013, p. 5). As shown in Figure 1.1, the finance, insurance and real estate share of total profits grew dramatically to a peak of 28 percent in 1992, before dramatic declines in 2000 and 2008 to 14 percent. During the same span, manufacturing share of profits fell from 53 percent to 14 percent.

In the context of the US nonfinancial corporations, stock market capitalization has increased from 40 percent of US GDP to 160 percent from 1947 to 2019, as shown in Figure 1.2. During the same time, the size of financial assets relative to GDP increased from 30 percent to 100 percent. The size of nonfinancial assets relative to GDP show no marked growth trend for the entire 


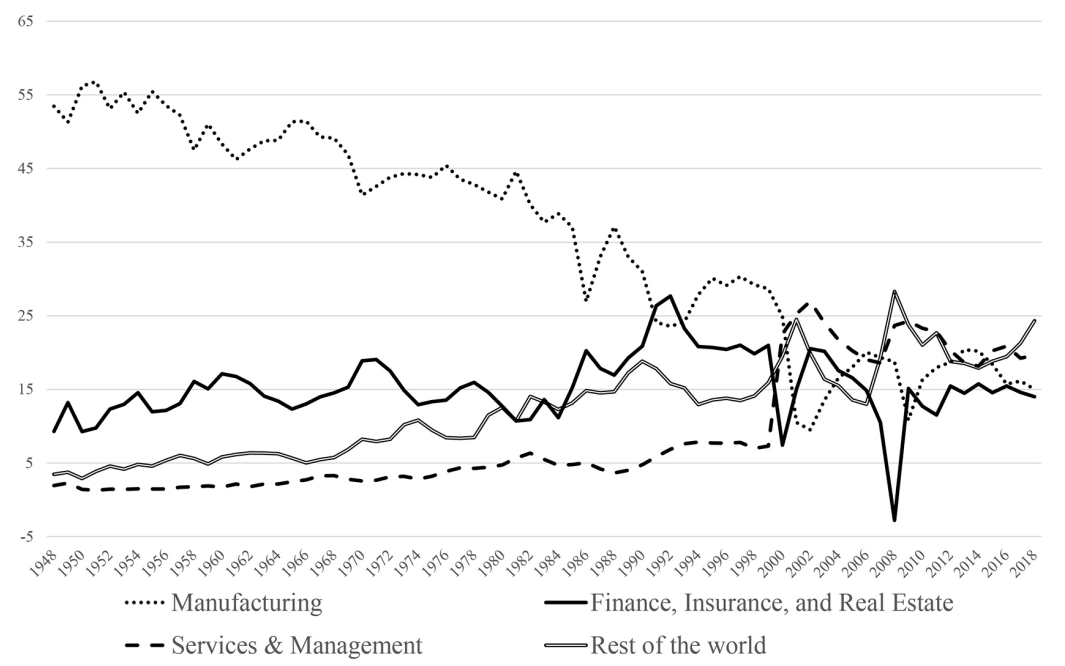

Source: Bureau of Economic Analysis, table 6.17B; corporate profits before tax by industry

Figure 1.1 US industry sector percentage of profits

period, rising to 140 percent of GDP in 1983 and then falling in 2019 to 120 percent, the same level as 1947.

Perhaps the broadest possible definition of financialization is simply to recognize that it describes a new method of finance, increasing and altering the rights of income. In this context, financial innovation allows risk and cash flows to be reorganized and transferred in ways that allow increased hedging, investing and speculation (Hu 2015, p. 350). As Karl Marx noted about the rise of the modern industrial capitalism, 'The wealth of those societies in which the capitalist mode of production prevails, presents itself as an immense accumulation of commodities' (Marx 1867, p. 1). The latest development of capitalism could be understood as an immense accumulation and proliferation of financial contracts, in which an increasing share of exchange is recast as a debt contract.

\section{Derivatives and Securitization}

In the financial industry, the changes demonstrate the rise of a shadow banking system. The term was coined by Paul McKulley at the Jackson Hole conference of the Federal Reserve in 2007. The shadow banking system is an outgrowth of the investment banking industry. Its financial innovations created a new and less regulated system for lending that had replaced, or extended, 


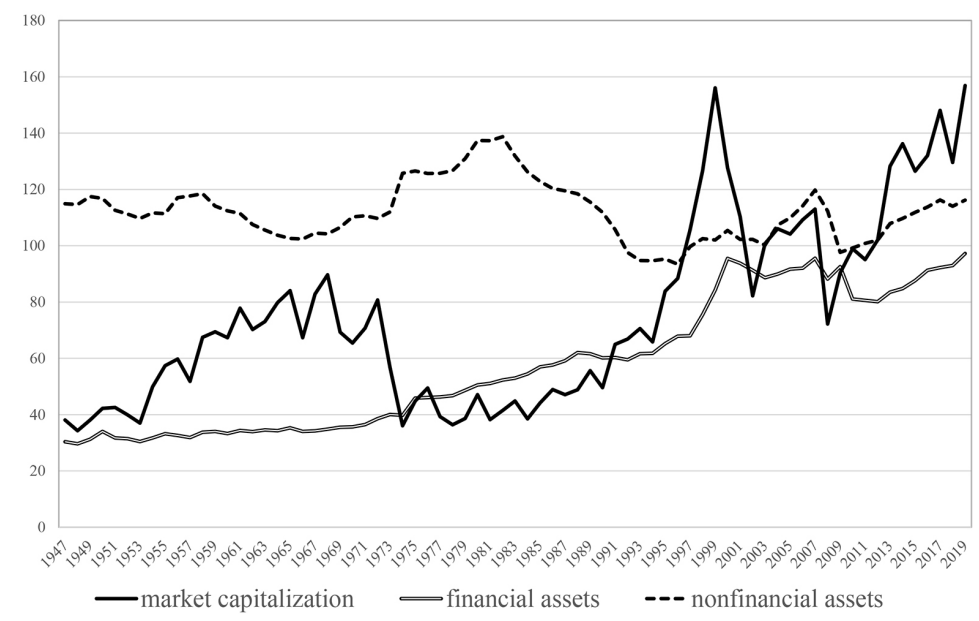

Source: Federal Reserve Bank flow of funds Z.1: B.103; LM103164103, FL104090005, LM102010005. F.103; FL103164113, FL103164123

Figure 1.2 Nonfinancial corporation market capitalization, financial assets and nonfinancial assets as percentage of GDP

older methods of credit. While financial innovation allowed for the creation of many new types of specialized financial assets, the two broad categories of derivatives and securitized assets are useful to develop.

A derivative is a security whose value is derived from an underlying asset or group of assets. Common derivatives include options and swaps. While derivatives have a long history, their growth and proliferation accelerated after the creation of the Chicago Board Option Exchange in 1973 standardized products and provided a new platform for their trading. Unique versions of these contracts are also created and traded on the over-the-counter market between private parties.

As an example, a futures option in a commodity allows individuals to trade contracts for the future delivery or purchase of the underlying commodity at a specified price and date. From an efficiency standpoint, an individual would be willing to trade in futures as a way to reduce exposure to future price changes and lock in a specified price for future delivery. Another individual, willing to accept that risk and hoping to benefit from future price changes, would be willing to buy such a derivative contract. While the example above focuses on the concept of hedging (or limiting) exposure to future price movements, any asset that changes in price can also be used for arbitrage or speculation. 
Another common derivative is the swap instrument. While swaps are traded on the over-the-counter market instead of exchange traded, they also provide a way to segment exposure to risk. As an example, an interest rate swap would allow two parties to trade the right to the distribution of interest from a loan for a specified and more stable payment. In this way, the interest rate swap compartmentalizes and prices a specific type of risk. The deepening of these derivative markets and their application to different forms of risk in commodities, bonds, stocks and currencies is justified as creating a more complete market and accurately distributing and pricing those risk exposures. As trading in derivative contracts has expanded, the notional or total price of global exchange traded contracts has increased to 600 trillion United States dollars (USD), while the gross market value of these contracts is currently estimated at 12 trillion USD (Bank for International Settlements 2020, p. 1).

Securitization is a process for bundling assets and creating a new bond based on the aggregate income flows of the underlying contracts. Common examples include the collateralized mortgage obligation (CMO) and the collateralized debt obligation. With a $\mathrm{CMO}$, individual mortgages with their individual risk characteristics are bundled together to create a pool of mortgages. The CMO bonds then securitize the interest and principal payments of the underlying mortgages. Because of the law of large numbers, this bundling reduces exposure to the volatility of the individual underlying assets. Depending upon the type of security, these securities are broken into tranches which provide ranked claims to the stream of income provided, with the highest tranche receiving the first claim to the underlying interest and principal payments. The bottom tranche, whose claims are satisfied last, earned the unfortunate label of 'toxic waste'.

With the rise of New Finance, the ability to hold and exercise multiple positions in equity and bonds has led Henry $\mathrm{Hu}$ to argue that the traditional corporate governance roles of stock and bond holders had been blurred. The ownership and obligations of stock and bond holders have become less transparent. Among other categories, this is described as the rise of the empty creditor and empty debtor positions ( $\mathrm{Hu} 2015$, p. 348). As one example, a stockholder may appear to have interest in the long-run profitability of a firm, but a large short bond position may provide a netted benefit from the bankruptcy of the firm. Because such positions are poorly disclosed, and can be considered immaterial to the performance of the firm, the ability to determine the interests of these agents is lost (Hu 2009).

As New Finance formed, changes were also under way in the older lines of credit. To compete in this new environment, traditional banking was transformed through the process of deregulation. The segmented lines of commercial banking in the US were removed, and the rapid consolidation of the industry was carried out, leading to the rise of mega mergers in finance that 
created banks that were 'too big to fail'. While previous changes in the rules for financial holding companies had already been implemented, the dividing line between commercial bank and investment bank incentives and practices was fundamentally erased by the passage of the Gramm-Leach-Bliley Financial Services Modernization Act of 1999. The merger of Citibank and Travelers insurance, approved prior to the passage of the Act, provides a useful example of this race to the top and the political forces arrayed to support it.

\section{The Endogeneity of Credit}

With the rise of New Finance, asset values become more endogenous and the business cycle more unstable. Because the risks of lending into individual markets is seen as contained by derivatives and securitization, the flows of credit into those markets can increase. Most notably, in the real estate bubble of the US, the willingness of institutional investors to purchase securitized assets allowed greater lending into the underlying market for traditional mortgages. As commercial banks sold raw mortgages into the process of securitization organized by investment banks, the flow of credit to mortgage markets increased and real estate prices rose dramatically. Credit could continue to flow as long as the appetite for the securitized products remained strong asset prices in the primary and securitized products could continue to rise, the value of collateral assets could increase, and further extensions of credit could continue.

The behavior of the business cycle, and the fluctuation of fundamental asset prices, can now best be understood with reference to a credit or leverage cycle instead of steadily progressing fundamental real values. The economy and its sectors boom and bust based on the extension or retraction of borrowing power - as it is extended to household borrowers, real estate speculation or corporate mergers and acquisitions. As noted by former GE executive, Zachary Abrams, 'Securitization is a way of bringing tomorrow's earnings into today' (Birger 2000 , p. 16). These methods of finance provide borrowers with a new way to gain liquidity, to convert expectations about the future into current purchasing power and to create new claims relative to the total level of productive capacity. It is important to point out, however, that financial innovation is not limited to these two instruments in the modern environment. The search for new ways of borrowing and increasing liquidity precedes these instruments and will continue.

Such innovations shift purchasing power into the present and create income claims based on future expected earnings of the corporation or financial assets. Over the past 50 years, this process has led to an increasingly endogenous money system, a leverage cycle where corporate management has focused on the acquisition and acceleration of asset bubbles in speculative forms of capital 
assets. These assets that have little to do with expansion of productive capital except as a secondary outcome of the process. As a practical matter, the asset bubbles have much more to do with the acceleration of claims on income than an improvement of a long-run equilibrium level of tangible and purposeful output. Investment has become a bubble on the stream of speculation.

The pro-cyclical leverage cycle - where asset prices rise based on additional credit flows - destabilizes the macroeconomy rather than improving its efficiency. In the crises that follow, asset prices begin to fall, access to credit to finance current operations is frozen and private financial markets and business engage in deleveraging. What first appears as a liquidity crisis quickly moves to a solvency crisis as firms begin to liquidate assets to satisfy creditors, while the value of assets falls. The result is a balance sheet recession. The primary focus of the firm shifts to returning to solvency, and any chance of recovery is delayed until that process has been resolved.

As the market for these assets declines, the ability of monetary authorities to support the private flows of liquidity and asset values becomes compromised. In the US case, massive intervention was required, short-term interest rates fell to zero, government programs directly intervened in bond markets with purchases of assets and the umbrella of federal guarantees was extended to investment banks as they converted into bank holding companies. The promise of monetarism, that the Federal Reserve could always intervene to stabilize asset values and maintain nominal aggregate demand, was not realized. While the profitability of banks quickly returned, the contraction had lasting real effects on households and the economy. Federal programs to support the ultimate debtor and bypass the traditional bankruptcy process did not appear in an appreciable scale.

This new system for extending credit has its analogue in the equity markets of the late nineteenth century. With the inclusion and mixing of intangible assets such as goodwill into the assets of the corporation, a new source of corporate credit had been created. Like the consistent underpricing of risk that fueled the bond leverage cycle of the late twentieth century, the expectations of future expected earnings helped finance the great American merger wave from 1895 to 1904. But the extension of current purchasing power based on expected future interest payments or profits comes at a price. It can evaporate. As noted by Alan Greenspan in 2002 in the aftermath of the dot-com bubble, '[t]he rapidity of Enron's decline is an effective illustration of the vulnerability of a firm whose market value largely rests on capitalized reputation. The physical assets of such a firm comprise a small proportion of its asset base. Trust and reputation can vanish overnight. A factory cannot' (Greenspan 2002).

While bonds and equity are unique assets with very different legal rights, they both increase credit, liquidity and current purchasing power. The recent wave of financial innovation did for bonds what goodwill did for stocks 100 
years earlier. While financial innovation was supposed to correctly identify, price and allocate risk, the total volume of activity and claims on income so created dwarfed the underlying value of real assets and income flows upon which they were based. Like goodwill, the buying and selling of risk generates claims to income that can evaporate. They are future-looking values. While New Finance was supposed to compartmentalize and price risk, the reality of wrong-way risk, where supposedly segregated risks combine to create greater risk, suggests the concept is as intangible as that of goodwill. In both developments of finance, the value of current contracts and securities became increasingly endogenous and forward looking, incorporating a greater degree of future expected earning capacity into the current pricing of assets.

\section{FINANCIALIZATION AND THE NONFINANCIAL CORPORATION}

The influence of New Finance on the operation and performance of the nonfinancial corporation can be seen in the discussions of the shareholder revolution and the rise of institutional investors known as money manager capitalism.

\section{Shareholder Revolution and Money Manager Capitalism}

As noted by Adolf Berle and Gardiner Means, the rise of the modern corporation led to the consolidation of managerial control and the broad distribution of share ownership (Berle and Means 1932). This freed management from their direct responsibility to the true owners of firms, so they could pursue nonproductive investments, empire building and improving their own circumstances at the expense of owners. The failed results of the conglomerate wave of mergers in the 1960s were used to illustrate how corporate management lost sight of their true purpose. Shareholder activism to discipline management and return their attention to maximizing returns to the shareholder was seen as a solution to the malaise of the 1970 s.

The shareholder value revolution is usually described as a response to the agency problem of corporate managers. Instead of distributing corporate profits to owners, management preferred to retain large excess cash flows. To resolve this issue, corporate management needed to be disciplined by shareholders to focus on maximizing share price and rewarding the owners of the firm (Lazonick and O'Sullivan 2000, p. 15). This revolution had the rhetoric of democratic action - individual shareholders collectively rising up.

The shareholder revolution had two separate goals for corporate managerial strategy - raising stock prices in secondary exchange markets and increasing the distribution of corporate profits. The stock option would focus the attention of management on these goals. Ultimately, this meant disciplining errant 
management by paying them more money. In recent years, the shareholder revolution, stock options and earnings management to drive share price have become a frequent target for critics. Corporate management has been criticized for pursuing short-sighted practice, failing to pursue long-term strategic investment and using the tools at their disposal to manipulate share price by subverting accounting conventions.

While the shareholder revolution is a useful narrative to explore these developments, some have pointed out that it has a mythic quality (Knafo and Dutta 2016, p. 772). In their work, they source the origins of financialization in the tools and practices of management in the 1960s. The mythologic force of the shareholder revolution in the 1980s, and the use of stock options it justified, simply provided a convenient narrative to empower and improve the rewards provided to management. While some hope to shift corporate focus towards a more equitable stakeholder approach following the crises of 2008, the removal of shareholder influence will not have the intended effect.

The empowerment of management to focus on maximizing share price dovetails with the rise of institutional investors that has been described as money manager capitalism. With the growing size and influence of mutual funds, pension funds and insurance companies interested in stable and well-performing portfolios, their ability to hold larger blocks of stock cemented the drive to focus on maximizing shareholder returns. Like the shareholder revolution, this also had a democratic tone. Individual households, investing in defined contribution retirement accounts, could be served by the institutional investors managing their combined funds to maximize return. The interest of every household became increasingly embedded in the financial motive.

The excesses of the 1980s and 1990s could be understood as a working out of the new rules of finance and corporate management (Davis 2010, p. 80). With the junk bond financing schemes of leveraged buy-outs in the 1980s, the market for corporate control would hand inefficient firms over to more focused management teams, who would then divest and spin off the unprofitable mistakes of earlier management. This period marked the growing role of private equity. Capable of highly leveraged investments outside the realm of public disclosure, they could speculate in the expanding financial markets, or make a firm private and divorce it from any other stakeholder obligations beyond maximizing share price.

The global financial crisis of 2008 and the Great Recession have fundamentally altered the popular narrative about the benefits of New Finance. If 2008 could mark the end of money manager capitalism, what would replace it? Will institutional investors enforce a shifting focus to broader corporate goals, or will money manager capitalism survive in some alternate form (Stout 2013, p. 1181; Wray 2009, p. 826)? The next phase of evolution is already in motion. 
During the past 20 years, the number of publicly listed US nonfinancial corporations has been in decline, the number of new corporations being created has declined, the average size of the firm has increased and the average age of existing public corporations has fallen. The ownership of corporate equities has been concentrated into larger block holdings by institutional investors. The result is a more efficient income-distributing version of the public corporation. It is more capable of controlling its equity finance and managing its share price, and it is more efficient at extracting and diverting its flows of income.

In 1975, the US had 4819 firms listed on the major public exchanges of the New York Stock Exchange, the National Association of Securities Dealers Automated Quotations and the American Stock Exchange. This number rose until 1997, when it reached 7507 listed firms. The number fell rapidly until 2003 and then fell more slowly. In 2015, there were 3766 listed firms, a number that is more than 20 percent (1053 firms) lower than 40 years before, and 50 percent (3741 firms) below its peak (Kahle and Stulz 2017, p. 70). From 1975 to 2015, the lifespan of firms on the SP 500 has declined from roughly 50 years to 15 (Stout 2013, p. 1179). Corporations are remaining or going private, others are failing and still others are being acquired by rivals.

The consolidated balance sheets and financial accounts for nonfinancial corporations included in the Federal Reserve Bank's flow of fund accounts provides an outline of the changes under way. One feature of financialization is the increasing role played by financial assets in the balance sheet of the corporation, more specifically, the role of intangible assets such as intellectual property rights or the accretion of goodwill through merger and acquisition finance. As shown in Figure 1.3, the share of financial assets and intellectual property as a percentage of tangible assets began to accelerate in the 1980s, rising from 42 percent to a peak of 123 percent in 2008. Since that peak, financial assets as a share of tangible assets fell slightly to 108 percent in 2019 .

Because intangible assets are not separated in the flow of funds accounts, it is not possible to show their independent elements. Estimates of the importance of intangible assets for US firms vary. As noted by Kahle and Stulz (2017, p. 75), estimates of the value of intangible assets have varied but increased over time. They report that intangible capital increased steadily from a little more than 10 percent of net assets (assets minus cash holdings) in 1975 to greater than 50 percent in 2010 . The amorphous intangible category of organizational capital is also seen as very important in the new center of business. For finance, high-tech and health industries, the ratio of organizational capital to property, plant and equipment increased steadily from 1995 to a peak in 2012 at end of the research data set (Kahle and Stulz 2017, pp. 75-6).

With respect to the assets and liabilities of the corporation, as seen in Figure 1.4 , nonfinancial corporate debt and loans as a percentage of sector GDP has grown from 45 percent to 95 percent. At the same time, corporate debt and 


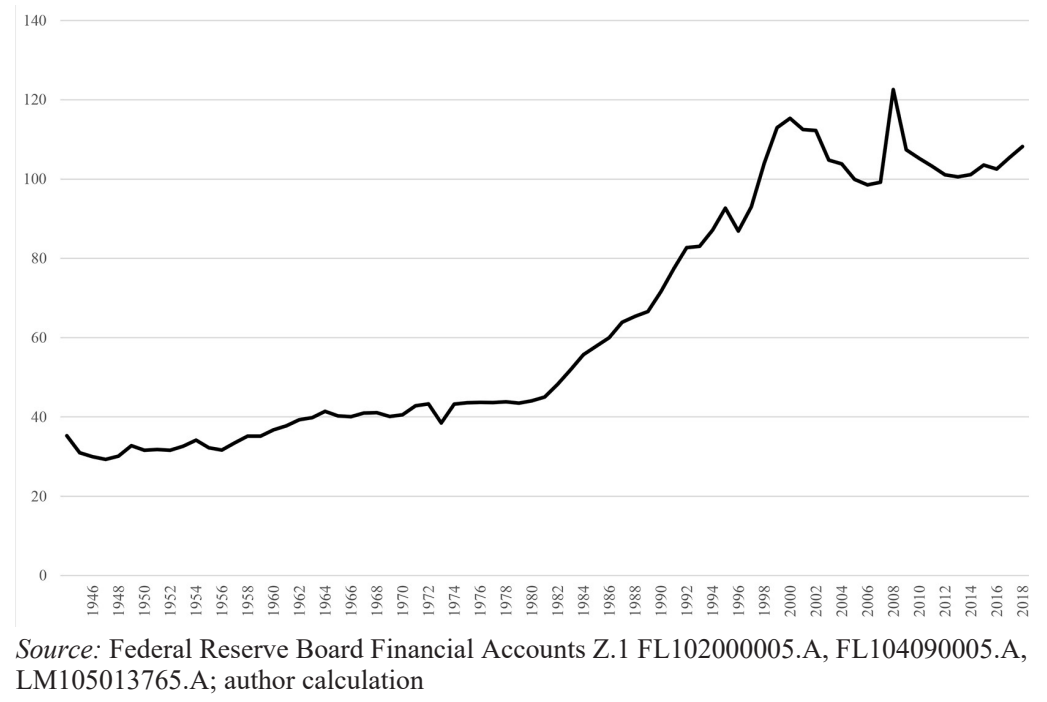

Figure $1.3 \quad$ Financial assets and intellectual property as percentage of nonfinancial assets

loans as a percentage of total liabilities has declined from 60 percent to 30 percent. This divergence can be explained because of the increased significance of unidentified miscellaneous liabilities. While the debt and loans of the corporation have grown in significance, those values are not capturing the new sources of corporate funding. While negative as a share of total liabilities until the mid 1970s, unidentified miscellaneous liabilities has increased to 29 percent of total liabilities in 2019 , the largest single category of liabilities.

While some authors have explained the category of unidentified miscellaneous assets and liabilities as a residual calculation, others have speculated on its contents or the reason for the growth of such a residual. The category of unidentified miscellaneous liabilities now surpasses every other major source of liabilities including corporate bonds, trade payables and foreign direct investment in the US. A similar situation has been seen on the asset side of the nonfinancial corporation. As a percentage of total nonfinancial corporate assets, unidentified miscellaneous assets surpassed the size of every other financial asset from 2002 to 2008, and in 2018 was surpassed only by US direct investment abroad.

As discussed in the literature of the shareholder revolution, the use of debt to buy back outstanding equity has increased rapidly in the twenty-first century. The phenomenon of stock buybacks is shown in the quantity of net equity 


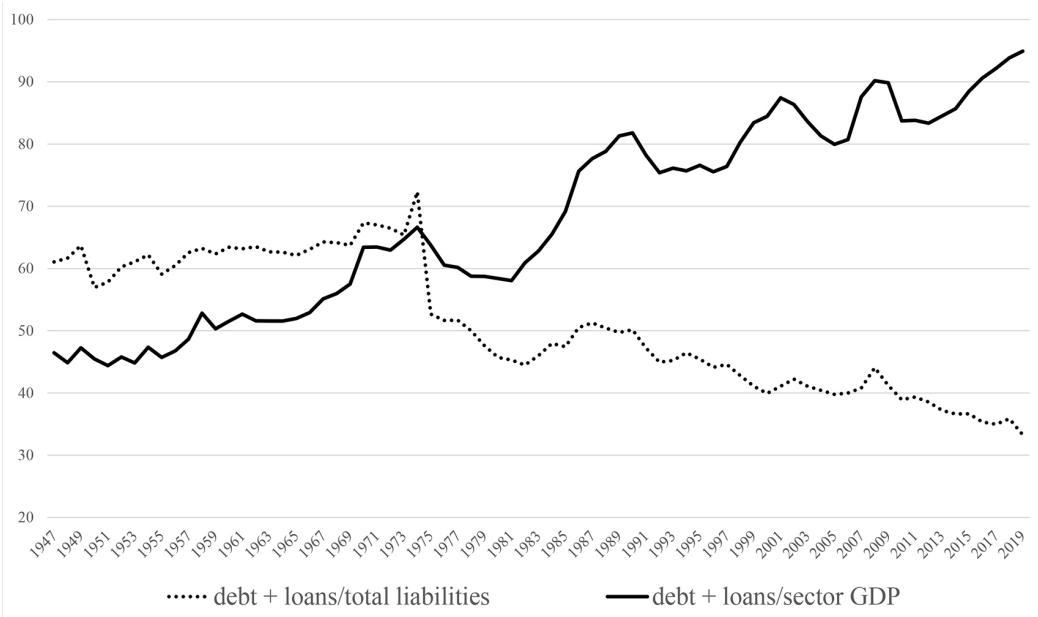

Source: Federal Reserve Flow of Funds Z.1: FL104122005, FL104123005; US Bureau of Economic Analysis, A455RC1Q027SBEA

Figure 1.4 Nonfinancial corporation debt and loans as percentage of sector GDP and total liabilities

issues, which considers the issue of new equity and subtracts the retirement of stock caused by repurchases and mergers and acquisitions. As shown in Figure 1.5 , net equity issues began to turn negative in the early $1980 \mathrm{~s}$ and peaked in 2007 at 700 billion USD. With the exception of 2009, negative net equity issue has been greater than 300 billion USD in each subsequent year.

Financing stock buybacks with debt has allowed the firm to stabilize and boost share price. These higher share prices provide a buoyant market for new issues associated with mergers and maintains the value of stock options. In this way, the individual share has become a more effective instrument for reorganizing the ownership of productive assets and ensuring income claims from secondary markets. While they have become a less significant tool for maintaining liquidity and working capital, they remain an important mechanism with which to reorganize industry and increase the income flowing to shareholders.

Another measure of the distribution of income from nonfinancial corporations is the payout ratio. A modified payout ratio shows the quantity of dividend payments and share repurchases as a percentage of corporate earnings. While share repurchases are typically funded with debt issues instead of earnings, this ratio still demonstrates the ability to reward shareholders by more effectively managing share price on the secondary exchange. As shown in Figure 1.6, the 


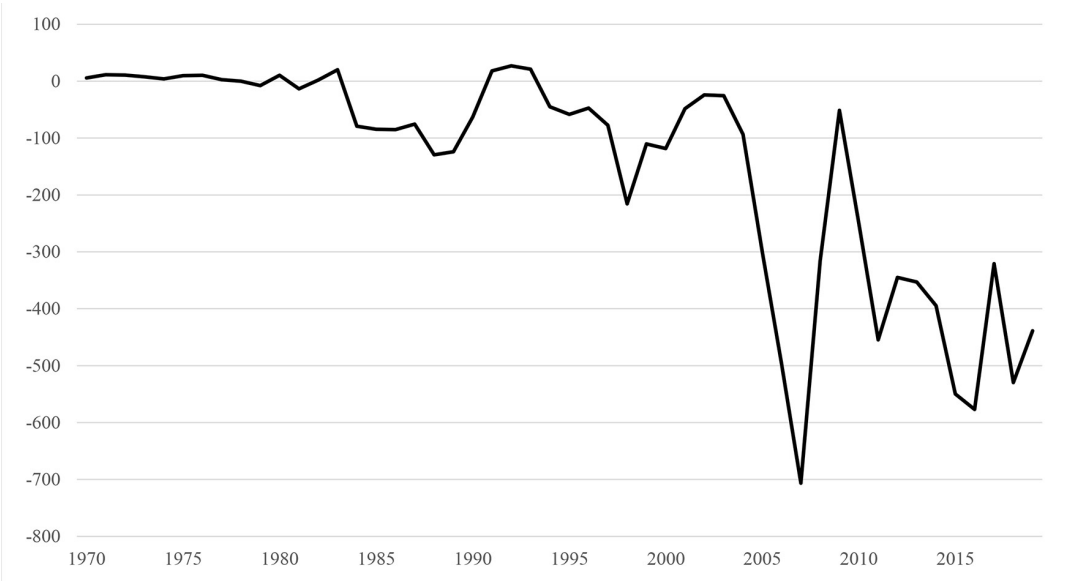

Source: Z1 Financial Accounts of the US, F.103 FA103164103.A; Federal Reserve Net Equity Issuance, www.federalreserve.gov/releases/efa/efa-project-equity-issuance-retirement.htm

Figure 1.5 Nonfinancial corporation net equity issues in billion USD

payout ratio was relatively stable and declining during the 1950s and 1960s, and began to increase in the 1970 s from a trough of 10 percent of net earnings. Since then, the payout ratio has become more volatile, peaking in 2016 at 77 percent of net earnings before falling back to 58 percent in 2019.

In the modern environment, the operation and performance of the corporation has been recast as sources of income to be managed with an ultimate objective of maximizing financial return. While the latest phase in the evolution of money manager capitalism has been described as the decline of the public corporation, it is more clearly an evolution of the system for constructing income claims. As recognized by Samuel Knafo and Sahil Jai Dutta, these developments precede the shareholder revolution and money manager capitalism (Knafo and Dutta 2020, p. 483). They will also follow it.

We have experienced something besides the more efficient allocation of capital and the achievement of a long-run growth rate path. Instead, the accounting scandals of the dot-com bubble, financial market instability and the aggressive use of stock buybacks financed with debt are simply three logical outcomes of the new environment. Such activities were documented during the National Association of Securities Dealers Automated Quotations bubble by the chairman of the Securities Exchange Commission Arthur Levitt and the Martin Act-inspired investigations of New York attorney general Eliot Spitzer. The rise of private equity firms, dark equity pools and the acceleration 


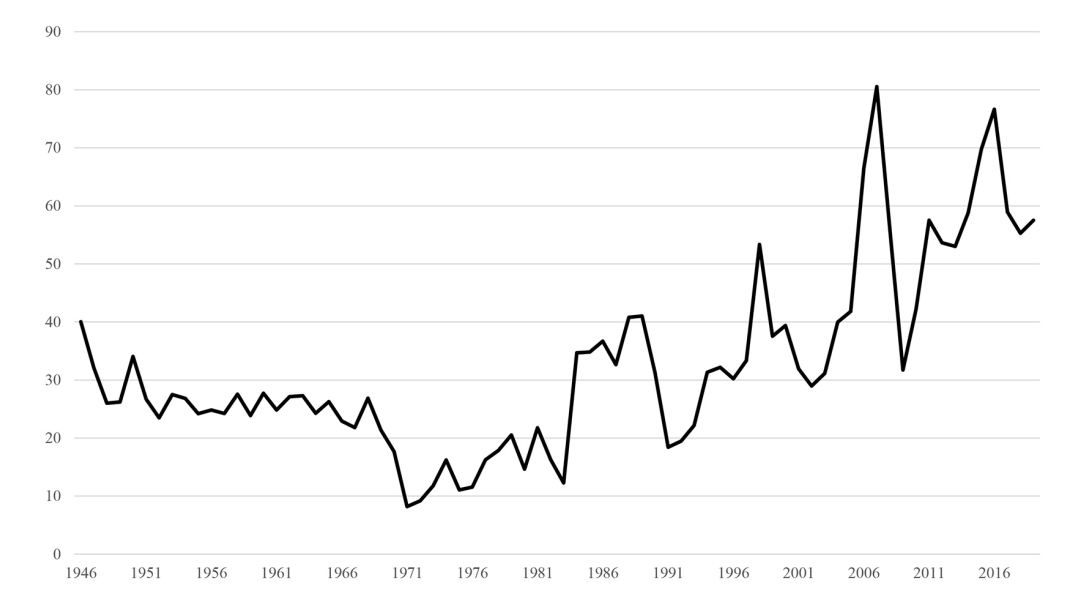

Source: Federal Reserve Flow of Funds Z.1: F.103 FA106121075, FA103164103, X.7 FA106110115

Figure 1.6 Payout ratio (dividends - net equity issues) as percentage of net earnings

of liquidity that is supposed to spawn a resurrection of 'managerial capitalism' will not alter this dynamic.

Some firms are choosing alternate legal forms. If their activities can be done more efficiently and with less scrutiny outside the organization of the public corporation, business and financial interests will pursue it. For the firms that remain, the new sources of finance, greater liquidity and enhanced control over their share prices have improved their ability to acquire start-up firms and accumulate intellectual property rights and other intangibles. For both, the growth of outsourcing, offshoring, nonbank holding companies and leasing and strategic alliances are replacing the system of domestic accountability previously associated with corporate managerial control. Taken together, these developments could be understood as the segmentation of the public corporation. The rise of money manager capitalism in the 1980s and 1990s was carried out in an opaque environment that has simply become dimmer. The information available allowed some of its abuses and tendencies to be publicly documented, even as the working rules for these practices became cemented in place.

Ultimately, the financialization of the nonfinancial corporation creates a more predatory, and penetrating, world of finance. This system is more prone to rising income inequality and endogenously created asset bubbles and collapse. But the forces that led to the age of money manager capitalism will not 
simply disappear. Instead, we should expect to see a more refined and effective version of money manager capitalism and the modern corporation develop. For its architects, this system will hopefully avoid direct criticism while maintaining the new status quo. To ensure the organization of productive assets for the purposes of innovation and productive investment, stable economic growth and mutual prosperity, some public policy response is necessary, to reveal, document and respond to the new reality.

\section{FINANCIALIZATION AND CORPORATE POWER}

The corporation in this modern era with its consolidation of the supply chain is reorganizing rights to income, reducing competitive pressures and consolidating economic and political power. These are not the results of profit-maximizing behavior as analyzed in the mainstream economics models. The mainstream models operate without an historical perspective and without an understanding of how law has evolved to accommodate business practices.

Large corporations dominate the national arena. Local corporations exercise outsized influence over the local arena through demands for tax breaks enforced by threats to move elsewhere and take jobs with them. Corporations are protected from infringement of the constitutional right to free speech because they are characterized by the Supreme Court as associations of citizens who have the right to free speech (Atkinson and Paschall 2011, p. 444).

The reorganization of industry beginning in the late nineteenth century has produced a new gilded age with income and wealth inequality at levels never before seen. It has led to a new layer of income claims that are even more tightly consolidated than experienced during the shareholder revolution of the 1970s. By 1975 the largest corporations held more than 70 percent of all corporate assets. Net income of the largest corporations has consistently been two thirds or more of all corporations' net income.

This structure of business and the role of finance have their roots in the widening of the market, evolution of the corporation in the nineteenth century and early twentieth century in response to it and the increasing use of the corporate form during the merger wave of 1895-1904 to facilitate the process of monopolization for the purposes of market control and stabilizing revenues. The focus on finance has imperiled the long-term health of the corporation as a going concern and projected the corporation into a position of power in the economy and politics.

In the subsequent chapters we will address the questions posed at the beginning of this chapter. Chapter 2 explains capitalism as a system passing through stages of development. Chapter 3 reviews the historical circumstances related to the widening of the US market for commerce and the transition from the age of scarcity to the age of abundance. Chapter 4 discusses the development of 
the corporation from the social invention formed to serve public purposes to its current position of power serving private financial interests. Chapter 5 reviews the evolution of the law from a system exercising social control over the corporation to one which supports the private financial interests, including the failure of antitrust law. Chapter 6 explores the evolution of the role of finance in the corporation. Chapter 7 presents three case studies on the effects of corporate power and financialization in the pharmaceutical industry, the hospital industry and the health insurance industry. Chapter 8 summarizes the consequences of the co-evolution of the economy, the corporation, law and finance and the prospects for constraining financialization and corporate power. 